\title{
The Impact of Social and Digital Medias on Senegalese Society
}

\author{
Ousmane Sall \\ Correspondence: Ph.D. Candidate at Huazhong University of Science and Technology, School of Journalism, \\ Information, and Communication, 6Luoyu Road 1037, Wuhan, China.
}

Received: May 15, 2017

doi:10.11114/smc.v5i2.2422
Accepted: June 1, 2017

Online Published: June 5, 2017

URL: https://doi.org/10.11114/smc.v5i2.2422

\begin{abstract}
West African countries especially Senegal, have a very rich history of written and oral communication based on their culture and traditions. Today, Senegal is inescapable about the adoption and use of new technologies in Africa. Senegal experienced a boom of cell phones users over the past 5 years in 2012 for example, we noticed " $88 \%$ mobile subscriptions" compared with " $46 \%$ mobile subscriptions in 2008 " \{world bank, 2013 . That explains mobile phones are no more to make a call or to send a text message but also to interact with people around and entertain. In fact, digital communication is expanding in all Senegalese spheres like the workplace, school, universities... in the latter half of the $20^{\text {th }}$ century before the explosion of social media, people only depended on old media like TV, Radio, Newspapers...to get informed. For this study, we are going to focus on how social media are impacting economically and politically on Senegalese society and how young people are managing the transition between traditional media and new media.
\end{abstract}

Keywords: interpersonal communication, social media, communication style, social networks, knowledge sharing

\section{Introduction}

When we talk about media, people first think about tools used for spreading information like TV or Radio or whatever. Social media is now a much-shared tool that helps people to interact with. It can be defined as a tunnel that links communities around the globe. As a matter of principle, media could deliver audio-visual or visual information even if viewers and listeners are not able to give spontaneously feedback to their interlocutor. There are several components in a procedure of communication. These components can be the sender, the receiver, and the message. Internet is the main and common item shared in the social media. Now in Senegal, social media are very developed and they are playing important roles in the society. The fact is, the online press is accessible and everybody can give his point of view about what's going on in the country. Social news, for example, interconnects people through political decisions and makes them have the differences comments and feelings on articles they read or videos they watch online. In Senegal, the most visited online press are Seneweb, Senenews, Senego, Dakaractu ... and they are appreciated because through these platforms people get informed and voice out their reactions to certain issues that directly hail them. Social networking is a branch of social media and it's useful. On facebook, for example, you can have your word on somebody's profile, joining several group chats and start different discussions with different people at the same time.

Nowadays, Senegalese society truly adopts all social media. It is already a way to build one's business. Online shops, for instance, are increasing in Senegal and producers exhibit their stocks on facebook or twitter to make customers have access on that and start ordering. It's quite popular nowadays because it's more convenient to anyone who does not want to go out for shopping.

\section{The Challenges and Opportunities of Social Media in Senegal}

\subsection{Interpersonal Communication}

For Erasmus, Bowler and Goliath, 1998: 5 interpersonal communication is done between two people or more. Bambacas and Patrickson, (2008:52) as far as they are concerned, show interpersonal communication skills have always participated to communication effectiveness. Van Staden, Marx and Erasmus-Kritzinger (2007: 25) paint the importance of interpersonal communication by saying: "Remember that good interpersonal communication and relationships are essential for business success." With rising numbers of social media, Senegal is developing in the area of social networking. Social media become the main canal to facilitate people interaction. Qualitative analyses of a recent study demonstrate children and youth in general between 12 and 32 are Senegal best users of social media. As a matter of fact, violence against children and cyberbullying are very noticed. 


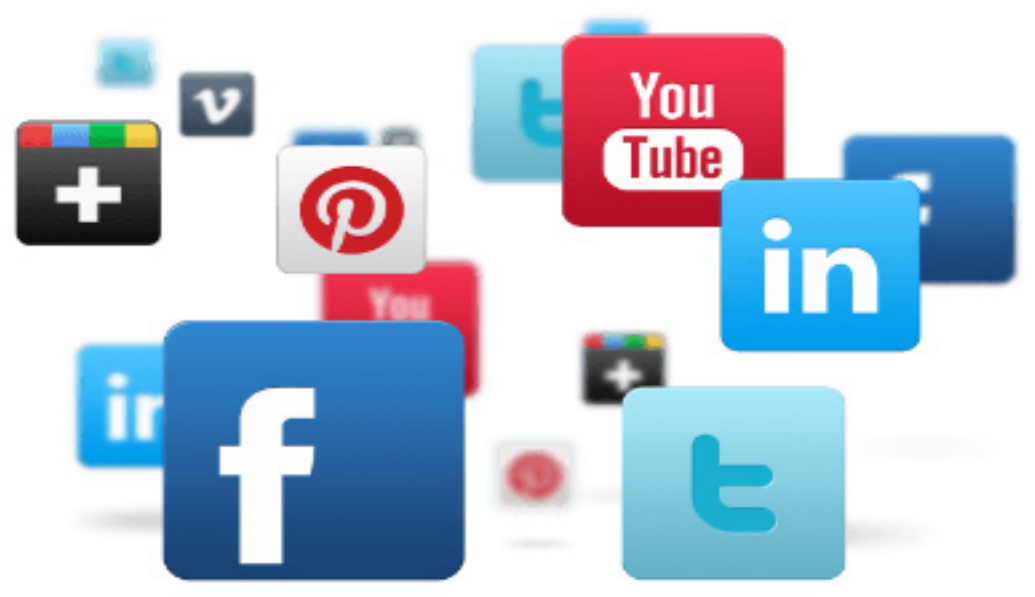

Staying always connected on social media is a routine activity that researchers have demonstrated to benefit young generation. Facebook, Twitter, WhatsApp offer opportunities to interconnecting with comrades and people around us. Since 2005, the number of adolescents using social media is staggering. According to a recent sampling in Senegal, $25 \%$ of adolescents connect on facebook or WhatsApp more than 10 times a day, $75 \%$ of children have mobile phones, and $30 \%$ use them for social media, $54 \%$ use them for chatting, and $24 \%$ use them for instant messaging. Connecting on social networking is a routine activity that children most share in Senegal. Many sites like Facebook, Twitter give opportunities to children for games and interacting. That's why parents must be more prudent about the way children using social media. Senegalese people have opportunities to interact now and change throughout many ways, and that helps to improve interpersonal communication as Paul Booth Professor of media and cinema at DePaul University in Chicago declares about the influences of social media between people of different places and different ages. "There has been a shift in the way we communicate; rather than face-to-face interaction, we're tending to prefer mediated communication," he argues. "We'd rather e-mail than meet; we'd rather text than talk on the phone."

For him, researchers highlight that humanity becomes more and more sociable but the way people interact has changed because of the explosion of new technologies that tend to reduce meeting between friends, families... Booth continued. "So while we're communicating more, we may not necessarily be building relationships as strongly." So, communication on social networks is now very useful and attractive in Senegal. Three main aspects appear when we talk about people interaction in Senegal. Firstly, when people sharing articles or videos via internet, they tend to trust everything they can see or watch so their messages become more and more shared. Second, their discussions are not voracious as they supposed to be in face to face. Last, they tend to follow and interact with people who agree with their points of view, so they aren't getting the same diversity of viewpoints as they have gotten in the past.

"Certainly, with every new communication technology comes to change in the style and type of interpersonal communication," Paul Booth said. "Obviously the bigger the influence of the technology, the more changes we see in communication styles."

\subsection{Social Media Marketing in Senegal}

It is a way of making business online in order to reach a bigger audience or customers you can communicate and share with. That helps for advertising and widening one's activities. Social networks are now a basic treasure for Senegalese to grow and spread their activities. They can cooperate with their customers get their ideas about products they offer to improve their services. Social media give opportunities to maintain strong relationships with customers even after the services offered to stay closer to them for their satisfactions. This cooperation between traders and customers through social media is something that traditional marketing cannot offer in any way possible. For example, in Senegal Geo-targeting is deeply used now that participates in delivering message out to a specific audience based on their location. Social media like WhatsApp and facebook keep us directly in contact with our partners. From a company facebook account messages and videos can be posted to reach followers in a specific country based on geographical parameters.

Senegalese marketers used to face many problems of ensuring their products reach customers in the shortest time. But now, with the help of social networks, specifically when it comes to sharing something about business, all you need to do is to share it on your facebook or twitter account. In Senegal, when a company has a regular presence on social media, it becomes closer to its customers. And by communicating with them through internet; you're more likely to understand them about their feelings and what they expect from you. Even if a company does not possess a website, most of its customers expect them to have it. More than $55 \%$ of consumers visit social media for buying or booking products. Social 
media are improving the way business is running in Senegal. Their impact on the Senegalese society has been nothing short of exponential.

If a business is suffering from low engagement on their social marketing, it's usually because it misses the identity of the customers. Buyers' identity is very useful in Senegal that helps to define and target the right people at the right place with the right messages they expect from the marketers.

When you have an idea about your target audience's age, occupation, income, feelings, pains, problems, obstacles, habits, likes, dislikes, motivations, and objections, then it becomes easier and cheaper to target them on social or any other medias. For example, the way Orange ${ }^{1}$ is strengthening its presence all around Senegal is remarkable and the latter has a strategic priority to make international development a driver to accelerate its growth by penetrating high-potential emerging markets throughout the country. This operation will also allow Orange to strengthen its positions not only in Senegal but also in West African countries as well. It will also enable the Group to create operational and marketing synergies with other countries where Orange is already established.

The development of their presence in Senegal confirms the dynamism of the country, as well as the tremendous growth potential of its business and its revenue.

Social Media marketers in Senegal have the opportunity to build and experiment with new methods and means to create demand, reach their customers, and develop important offers for them. Senegal consumer markets can provide the perfect example to explain the disappearance of traditional marketing.

Despite infrastructure challenges, E-commerce is growing in Senegal and we are expected to see $30 \%$ annual for the next decade. E-commerce in Senegal could be very profitable for everybody; it will just take time and effort. Senegalese authorities must understand that to make the web works and accessible.

Senegal has a rapid growing communications infrastructure, that's why the Smartphone market is giving opportunities to the whole population to have access to the internet and also to be close to online shops.

\subsection{Social Media is Changing Education in Senegal}

From kinder Garden to university, social networks are still influencing students' behavior, so school administration and parents are using them to communicate with students living conditions. Students use social media to share courses, downloading articles and sometimes find part-time jobs as well. Social media has exploded and has transformed the way people interact on the personal level and then on the education level. The possibilities for social media in Senegalese education are exciting. Teachers don't need to tell students about the important of social media they do already know about it, so it makes sense to talk to them in the online world they already spend most of their time. Now, students are corresponding and interacting with other students around the world via social media; and school authorities are doing their best to facilitate that connection. As Katie Benmar ${ }^{2}$ spotlighted in one of his articles published in Education Week op-ed, (April 2015)

"Learning how to use social media and technology to engage students is potentially very beneficial for our learning, and some teachers have taken the first step. At my former middle school, one math teacher has her own Instagram page where she posts homework assignments and things that she taught that day in class. This way, when kids are checking their feeds, homework assignments and reminders will inevitably show up on the screen. This is a good way to get students' attention and remind them in a relatable way about upcoming tests or homework. Although this teacher is using social media and other technology in a smart way, she is a minority in a sea of teachers and educators that I have known."

Social media integration does not have to stop only with students and professors, Senegalese school authorities are thinking to join social media into their respective programs. That could be easy because some parents even had facebook when they went to college. And they may even have a facebook account about parenting. It's only natural that school administrators are using social media to share school news and building community with these student parents to create a closer atmosphere between school and home.

Accessibility on internet in general are improving Senegalese education. Students, with the help of the social medias, now have access to all form of courses. Some books that cannot be found in libraries and research centers are now available online. The use of search engines such as Coursera and Google Scholar is helping many students in their researches. The

\footnotetext{
${ }^{1}$ orange is the incumbent Senegalese telecommunication operator

${ }^{2}$ Katie Benmar is a freshman at Roosevelt High School in Seattle, where she plays jazz piano in one of the school's bands. She's also interested in astronomy and the physics behind it.
} 
world is now a small place where there is free circulation of knowledge and information. Educational problems that students encountered are being discussed and solved online through the help of online counselors.

Distance learning is made possible now in Senegal by the use of social media. Many universities and especially Virtual University of Senegal (VUS) are now offering online courses to students. The social media has brought education and learning very closer to our doorsteps.

For Hassana Alidou, chief of the Basic to Higher Education Section for UNESCO Dakar, "education system in Senegal struggles to cope with several challenges since 2000, such as the abundant student who frequent the University of Dakar (UCAD).The rapid generation of private institutes of higher education."

It's no surprise that Senegal has this improvement in its education system. Today's students are communicating and sharing experiences on social media. Using the power of different networks and engaging content, the force of social media help to attract students, interact with them.

School authorities can make videos about campus life to convince student from high school to do their best in order to join the university, perhaps a YouTube channel would be enough in Senegal if we consider Senegalese population.

Each university or school in Senegal has to create its own account on social media; that will participle to control students by following them on their respective social media like facebook twitter, myspace...That sounds difficult but that can help to be closer to students.

At university, many departments are available on social media, that is useful to communicate with students about courses, exams, homework... it is a way to constantly collaborate with students and teachers to make the university a better place. By communicating openly, individuals can share best practices and learn from other people on their own campus. It's no secret that universities are perking up to the power of social media and devoting more resources to this area. As universities expand their social media endeavors, strategy, training and cross-campus collaboration will be critical.

\section{Social Media, a Tool to Shape Senegalese Political Views}

3.1 Social Media, an Opportunity for Democracy in Senegal

Social media make Senegalese people closer to the political fields, people are now holding political discussions like never before facebook, Twitter, and other platforms are ways to share and give one's point of views about what's going in the country. Social media allow exploring new things. They're about creating a comfortable place to stay informed. That's why Juana Summers, an editor for CNN politics said in her writings "One of the great things and one of the horrible things about social media is that everyone can have their say, It's kind of a marketplace for ideas. And some voices that sometimes are not correct or have a very partisan slant can oftentimes get amplified."

Living in a democracy means that all voices can be heard and that's what everybody does understand in Senegal. They have the ability to debate about any political news by respecting those with an opposing point of views. Nowadays Internet, Smartphones, and social networks are almost accessible around Senegal. That phenomenon helps to share real information because traditional media like radio, TV are sometimes controlled by the government. It serves to connect people for social uprisings or to debate about abuses of the local regime.

This situation is valid in all around Africa where the population is going to reach " 2.4 billion in 2050 " according (UNICEF, 2014, GENERATION 2030 Africa). Today young generation almost represents the African population. It is then high time for politics to invest on social media and include youth in the process of democracy. In the other hand, online debates can be held to share political point of views around the world so that every Senegalese has an idea about how democracy goes on in the country. Then, the government now understands suppression the rights to freedom of speech and gather wherever they want can frustrate people and that leads straight to social uprisings. This kind of suppression makes the country leave its objectives for democracy behind. In Senegal traditional media do not offer full information and the freedom of speech is sometimes called into question. So, the best way to be informed about political affairs is to stay connected on social media. Even though we notice an important volume of fake information because nobody is controlling where this information is coming from, and people are considering the right to criticize the government as an element for democracy.

Senegalese people now use the force of social media and claim best living conditions from the regime. These new media are considered as a public utility their importance is even noticed in Senegalese cultural, sportive and economic sphere. Nowadays, the Senegalese communication system is truly improved and it seems difficult for the local government to monopolize public spaces. Internet becomes a requisite tool to all African countries to break off totalitarian regimes and promote good governance to a near future.

Most of the African government know about the liberating force of social media and are progressively censuring them and pass sentence of years on those using them to awaken people. Online publication against an ordinary regime is sometimes 
prohibited and social media activists are often condemned for criticizing their respective governments. Then in order to prevent people from sharing bloggers articles or opponents point of views many governments in Africa monitor and intercept everything that goes on online. That's the case in Ethiopia where the government possesses its own telecommunication network called Ethio Telecom. It's the same in Eritrea also where the local government controls everything through its own company named Eritel and everybody needs to use government gateway otherwise you won't be informed.

Earlier this year, Zimbabwean President Robert Mugabe said "We want general technology in our country to be advanced so the mobile phone is not just a feature phone but can be used to discover news, record news and to share with others via apps like WhatsApp. However, there's a lot of bad stuff on the internet. Some people use the internet in bad ways. It's everywhere. But the Chinese have put in place security measures and we look at these so that we stop these abuses on the internet," he was explaining how his opponents took the advantage of social media and new technologies to disturb the local regime.

Senegalese people as far as they are concerned, take the advantage of new media to receive an alternative source of information and to be aware of the government propaganda. That's why it becomes more and more difficult disclosing wrong information around the country. Since the $1960 \mathrm{~s}$, most African leaders centralized traditional media, such as radios, newspapers, television to share information. Most of them used to manipulate the real information they prefer to praise themselves through propaganda because all of these media belong to the state. They never miss criticizing civil societies, oppositions as well.

Today, traditional media firmly controlled by governments give way now to mobile phones, laptops, tablets... This proliferation of new media opens new ways to establish platforms of communication and to get normal access to the political sphere.

\subsection{How Are Social Media Destroying News in Senegal?}

New medias help us to have full accessibility to information than before but they are changing our perception of each other and presenting a new method of journalism in Senegal. The lack of credible journalists is felt in the whole country because people cannot yet make the difference between what they read or watch online and what they learn from an official source. Local television and radio stations like Senegalese Radio Television (RTS), Walfaadjri Group and Groupe Future Medias (GFM) are suffering from this crisis because they don't get the audience they expect from the people which still provide the vast majority of their revenue. Don't get me wrong social media have so many benefits and we all aware of this. You can meet people online with social media, keep in touch with people online, you can get all the latest news through social media, you can post about your own life through social media and some people are actually having amazing opportunities and making money because of social medias. But social media obviously has its perks; it's sometimes easy to forget that everything we see and read online is not always the reality.

For better or worse, social media has forced its way into Senegalese journalism and have become a news source not only for the population but for journalists as well. New from social media are shared as quickly as that you don't have time to check if that's official or no.

That's to say social media make to spread false information easier and manipulate public opinion. On internet, we believe and comments ideas from persons we already consider like friends or followers. However, social media are very useful platforms to be interested in one's country politics, but we don't yet know how to use them in common good. In fact, Daniel Kahneman in his book entitled Thinking, Fast and Slow, highlights the same situation. That's what he called "fast thinking," for example we collect ideas around us and ignore where they exactly come from. It's very easy to denigrate somebody's identity on social media than in real life. So to avoid that people have to do their best to confirm information they pick up online through telephone or interviews. For instance, when we see something online, we must not be lazy to check the source before believing or spreading such information. People have to be credible in their use of internet. Photos, video are increasingly posted online by individuals and all of that can be manipulated. In Senegal, social networks are now very powerful and people always focus on what they get from social networks, for example, an old photo can be updated as if it becomes very new. Social networking sites, such as Seneweb.com, Senego.com, Dakaractu.com are playing important roles in Senegalese society. Their audience is extending over traditional media. Internet is an open door and everybody has access to it even if the divulgation of wrong information is increasing so far. Without getting too philosophical about the nature of the reality, we have to admit that our viewpoints of the world depend on the facts we face in everyday's life. However, the way our access to the news is currently mediated means we are more susceptible than ever to being misinformed. As Katharine Viner, an editor of the Guardian explained: "It can become very difficult for anyone to tell the differences between facts that are true and 'facts' that are false." It's an obligation to consider the volume and rapid dissension of online misinformation. When we focus on media, we face big data. Then, reading many 
tweets is not enough to believe everything that goes on around us. We need to go beyond social media comments to evaluate the context and the motivation of these data.

Roughly speaking, we have to know that every case of misinformation is exceptional and misinformation doesn't deserve to be considered at all. In term of interpreting misinformation, the human evaluation will remain essential to put information into context, and context is almost what that's all about.

\section{Risks of Social Medias on Youth in Senegal}

\subsection{Sexual Scandals}

Now, people are sharing sexual messages or videos throughout internet. Most of the Senegalese teens possess a mobile phone or computer that is why this fact is gaining ground, especially in school, universities... Teenagers are not yet aware of the danger and the powerfulness of internet sometimes they take easy sharing semi-nude or nude pictures with their girl or boyfriend. And with the lack of vigilance, these pictures can be exhibited on social media. This raises a scandal and consequences like exclusion from school emotional distress are going to follow. Actually, teens want to please their partners via facebook or WhatsApp and don't really realize how serious their acts are. Today, Senegalese teens find themselves in a unique position for example they look and talk like adults, but they are far from to be mature. This phase of development is natural, but when technology is coupled with the lack of experiences it can create vulnerabilities for our youth. Children are growing up in a global village we couldn't image 20 years ago. Internet and Smartphone bring them closer. So distance is no more an obstacle to entertain or have fun. They totally change the way teens dating, socializing, and communicating between them.

Technologies offer many opportunities so that strict measures and responsibilities must be set.

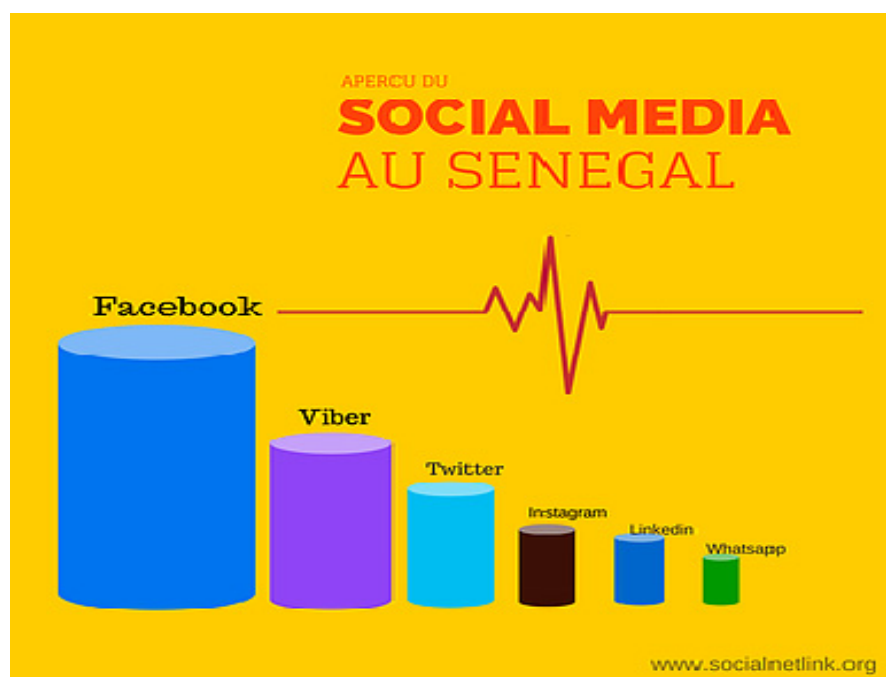

Figure1. Most popular social networking site in Senegal

\subsection{Social Media Leads to Youth Social Isolation}

The digital landscape has put more pressure on teenagers, and we all aware of this. There are so many social media: facebook, Twitter, Instagram, Snapchat.... Social network leads to addiction if kids are not controlled. Teens spend lots of time on social media instead of concentrating on useful tasks. This fact lowers their motivational level because they only enjoy chatting with friends, games, music... they don't take the advantage of technologies to improve their knowledge. Internet not only brings people closer but also creates social isolation because children prefer to be concentrated on what's going on their mobile phone than interacting with people around them. According to many scientists, social isolation can lead to emotional distress, anxiety, and many other consequences.

\section{Conclusion}

10 years ago social media seemed mostly a fun and useful marketing communications platform. But now, it would have difficult to anticipate the importance of social media all around Senegal. Social media have become a primary source of news and entertainment. And then, facebook and WhatsApp are also playing an important role in sharing news and local information. But in countries where the press has been weakened or controlled, having outlets to share news has been more important. Local newspapers do great work across the country, but they also need social media to reach as many readers as possible, particularly younger ones. 
All to say that social media in Senegal has been a lot more than just than sharing photos, videos and funny. Social media has been so influential and consequential in the lives of young Senegalese over the last five years that's why people now target social media specifically for advertising and political protests.

Nowadays, the world is a global village. Everyone is connected to one another in this vast throughout the force of internet. As Marshall McLuhan, a philosopher of communication theory said in his writings "The new electronic independence recreates the world in the image of a global village." This electronic independence is inherently dependent upon the Internet. It highlights the lives of thousands of people by spreading knowledge around the globe, thereby making us global citizens.

\section{References}

Alidou, H. (2012). Improving the quality of higher education in Senegal. UNESCO Office of Dakar. N.p., 19 Mar 2012. Web.28 Oct 2013.

Benmar, K. (2015). My Favorite Teachers Use Social Media: A Student Perspective. Journal of Education Week, $34(28), 22-23$.

Delaunay, K. (2012). Education in Senegal: inequality in development, Institut De recherche pours le development. 2012.

Erasmus, L. E., Bowler, A., \& Goliath, D. (2016). Effective Communication: Getting the message across the business. Goodwood: Afritech.Ignan,C How Does Social Media Shape Our Political Views? KQED, Learning, 2016.

Gumede, W. (2016). Social media keep Africa in check, African independence. 2016.

Kahneman, D. (2011). Thinking, Fast and Slow. Farrar, Strauss and Giroux. 2011.

Leslie, M. (2002). The Internet and Democratization. Hyden,G et al. (2002).Media and Democracy in africa.

McLuhan, M. (1962). Gutenberg Gala.University of Toronto Press. 1962.

Obijiofor, L. (2010). New Technologies as Tools of Empowerment: African youth and Public Sphere Particiapation. In wasserman et al.(2010). Popular Media, Democracy and Development in Africa.

Porta, D. (2012). Communication in Movement. Social Media as Agent of Participatory. In Lorder.(2012). Social Media and Democracy: in Participatory Politics.

Summers, J. (2016). How Does Social Media Shape Our Political Views.2016.

Van Staden, M., \& Erasmus-Kritzinger. (2007). Getting the Message Across in Business.

Viner, K. (2016). How technology disrupted the truth, the guardian,2016.

Bambacas, M., \& Patrickson, M. (2008). Interpersonal communication skills that enhance organizational commitment. Journal of Communication Management, 12(1), 51-72. https://doi.org/10.1108/13632540810854235

http://www.socialworktoday.com/archive/051313p10.shtml

https://blog.hootsuite.com/social-media-for-business/

data.unicef.org/resources/generation-2030-africa-child-demographics-in-africa/

\section{Copyrights}

Copyright for this article is retained by the author(s), with first publication rights granted to the journal.

This is an open-access article distributed under the terms and conditions of the Creative Commons Attribution license which permits unrestricted use, distribution, and reproduction in any medium, provided the original work is properly cited. 